Revue belge de géographie

\title{
Women and irregular mobility flows in the European Ultraperiphery: the example of the Canary Islands
}

Les femmes et les flux de mobilité irréguliers dans l'extrême périphérie européenne: l'exemple des Iles Canaries

Josefina Domínguez Mujica and Raquel Guerra Talavera

\section{OpenEdition \\ Journals}

\section{Electronic version}

URL: http://journals.openedition.org/belgeo/12534

DOI: 10.4000/belgeo.12534

ISSN: 2294-9135

Publisher:

National Committee of Geography of Belgium, Société Royale Belge de Géographie

Printed version

Date of publication: 30 June 2005

ISSN: 1377-2368

\section{Electronic reference}

Josefina Domínguez Mujica and Raquel Guerra Talavera, "Women and irregular mobility flows in the European Ultraperiphery: the example of the Canary Islands", Belgeo [Online], 1-2 | 2005, Online since 05 February 2021, connection on 05 February 2021. URL: http://journals.openedition.org/belgeo/ 12534 ; DOI: https://doi.org/10.4000/belgeo.12534

This text was automatically generated on 5 February 2021.

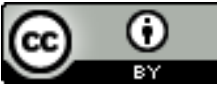

Belgeo est mis à disposition selon les termes de la licence Creative Commons Attribution 4.0 International. 


\title{
Women and irregular mobility flows in the European Ultraperiphery: the example of the Canary Islands
}

\author{
Les femmes et les flux de mobilité irréguliers dans l'extrême périphérie \\ européenne: l'exemple des Iles Canaries
}

Josefina Domínguez Mujica and Raquel Guerra Talavera

\section{Introduction}

1 The Canary Islands, which have historically served as an international crossroads, have, especially since the 1950s, experimented a radical change in terms of migrational conducts. Traditionally, the Islands had witnessed recurrent emigrational flows to South America, but from the 1960s and 70s onwards, and as a consequence of the vast expansion of their tourist industry, the Islands became the point of reception of new migrational flows (Martín Ruiz, 1987). However, it is during the second half of the 1980s, once the Kingdom of Spain has joined the European Union (1986), that the number of registered foreigners displays a remarkable increase. The peak is reached towards the end of the 1990s, when the registration of new residents in the Islands reached very high figures, which would, nevertheless, be considered as moderate or low in the context of European countries (in 1999, foreign residents on the Islands represented $4.09 \%$ of the total population). During this last migrational phase, the flow of immigrants arriving and settling irregularly on the Islands has acquired a notable dimension (by the year 2001, there were 97,950 foreigners registered in the census of the Canary Islands, and during the extraordinary regularization procedure that took place that year, 19,187 applications were presented .

2 It is difficult to characterize these immigrants from the point of view of their demographic sources. There are no statistical documents concerned with immigrants who, by the very nature of their irregular arrival, remain invisible. We have therefore tried to approach these flows from multiple perspectives. We have made use of data 
collected from the applications for work and residence permits submitted by foreigners at the Delegación del Gobierno in the Canary Islands (1999), as well as data collected from the records registered during the extraordinary regularization procedure that took place in 2000, when the Law Governing Foreigners $4 / 2000^{1}$ came into force, and data collected from the extraordinary regularization procedure for reasons of rootdness of the year 2001, undertaken as the implementation of an order in council developed in the law above ${ }^{2}$. We also resorted to two important humanitarian organizations, the Spanish Red Cross and CEAR, the Comisión Española de Ayuda al Refugiado (Spanish Commission for Assistance to Refugees), which gave us the opportunity to study the information contained in their files regarding foreigners who had approached them looking for assistance and advice. Finally, we also held interviews with some immigrants involved in the extraordinary regularization procedure at the local offices of the two organizations mentioned above.

\section{The feminisation of transnational migratory flows}

Over the last few years, women have taken on a role of greater importance, to such an extent as to dictate the need to approach migrational flows from a gender perspective. The feminisation of poverty all over the world has brought about the feminisation of transnational emigration.

4 At the beginning of the $21^{\text {st }}$ century, a greater presence of women in migrations abroad has been noticeable in Spain, and particularly in the Canary Islands, a territory that constitutes the European Union's southern border. The extraordinary processes of regularization that took place in 2000 and 2001, quoted above, have enabled us to become acquainted with the weight acquired by irregular female immigration in a geographical area where the intensity of these migrational flows is a relatively recent phenomenon. The applications for work permits submitted by women at the Delegación del Gobierno in the province of Las Palmas in 1999 amounted to $24 \%$ of the total number of applications. According to some of the NGOs that deal with immigrants on the island of Gran Canaria (Comisión Española de Ayuda al Refugiado, CEAR, Spanish Commission for Assistance to Refugees - and the Spanish Red Cross), the proportion of women among those who requested help or information amounted to about a third of the total number.

5 There is a slight trend towards an increase in the number of women, as can be seen in the chart that reflects the evolution of immigration (figure 1), elaborated on the strength of the data provided by the records of the Comisión Española de Ayuda al Refugiado. 
Figure 1. Evolution of immigration according to data provided by Spanish Commission for Assistance to Refugees.

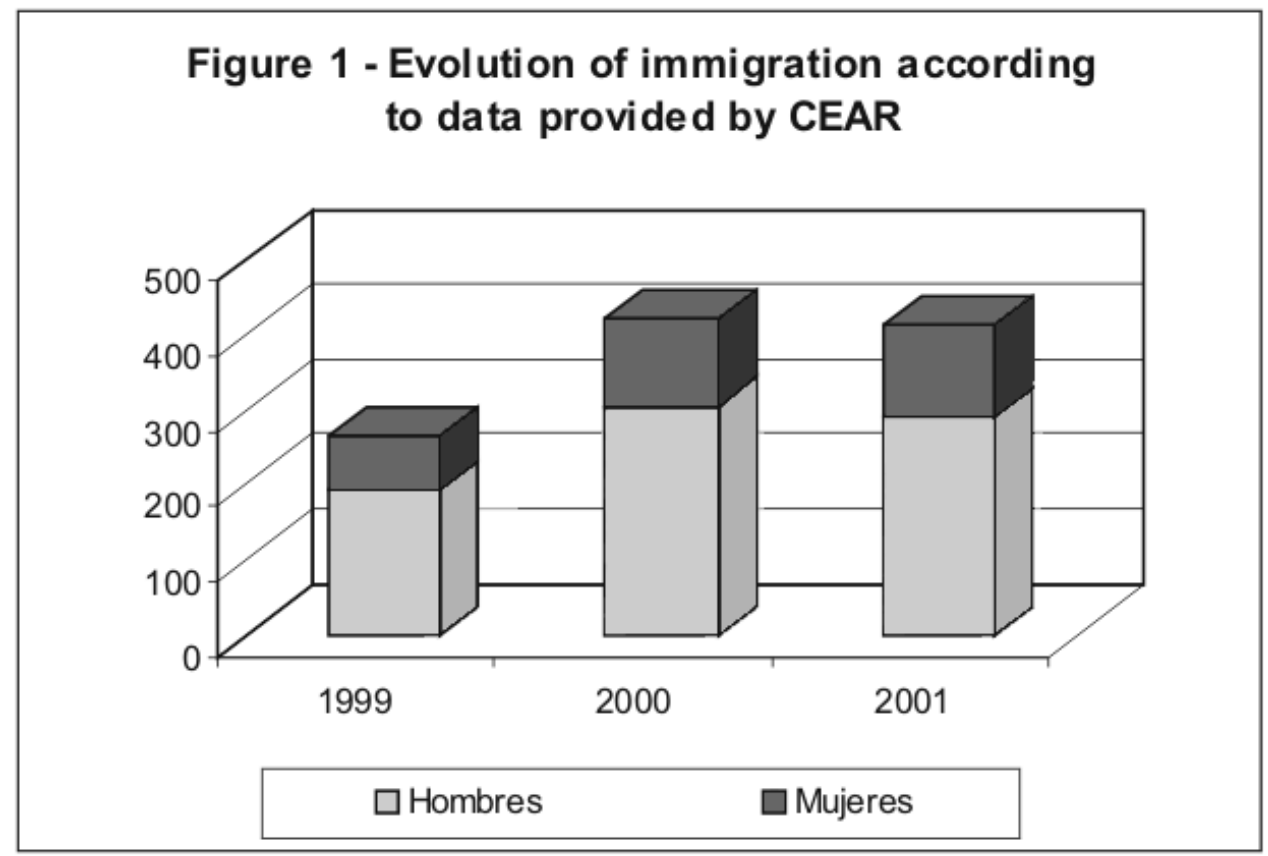

Foreign immigrants to the Islands are currently identified as belonging to two main groups. Firstly, those who come from developed countries, mostly Western Europe, who, highly qualified and taking advantage of the freedom of movement in force within the European Union, come to the Canaries for reasons of work or simply to live. In this latter case, it is the Islands' weather that acts as a magnet for these men and women to make the Islands their home either for long periods of time or simply for good. In the former case, it is the extraordinary development of the local labour market linked to the Islands' tourist industry. The presence of women in this case is very high, over $50 \%$ of the total number of immigrants.

7 The second main group of immigrants is made up of those who come from less developed non-European Union countries, who face severe problems concerning regularization, employment, housing and integration (Domínguez, Díaz and Parreño, 2001). These less traditional migrational flows have become much more intense over the last few years on the strength of cultural similarities in the case of South American immigrants, geographical proximity to Africa and the development of the Islands' informal economy. Men and women make up this second group in different proportions and, as quoted above, women amount to about $30-35 \%$ of the total.

The peculiarities of irregular migratory flows seem to favour a lesser participation of women, as if economic hardship and the decision to emigrate for reasons of political instability, persecution or survival affected men more than women.

\section{The heterogeneous characteristics of the different groups of immigrating women: cultural areas of origin and migratory projects}


Figure 2. Provenance of irregular (female and male) immigration flows.

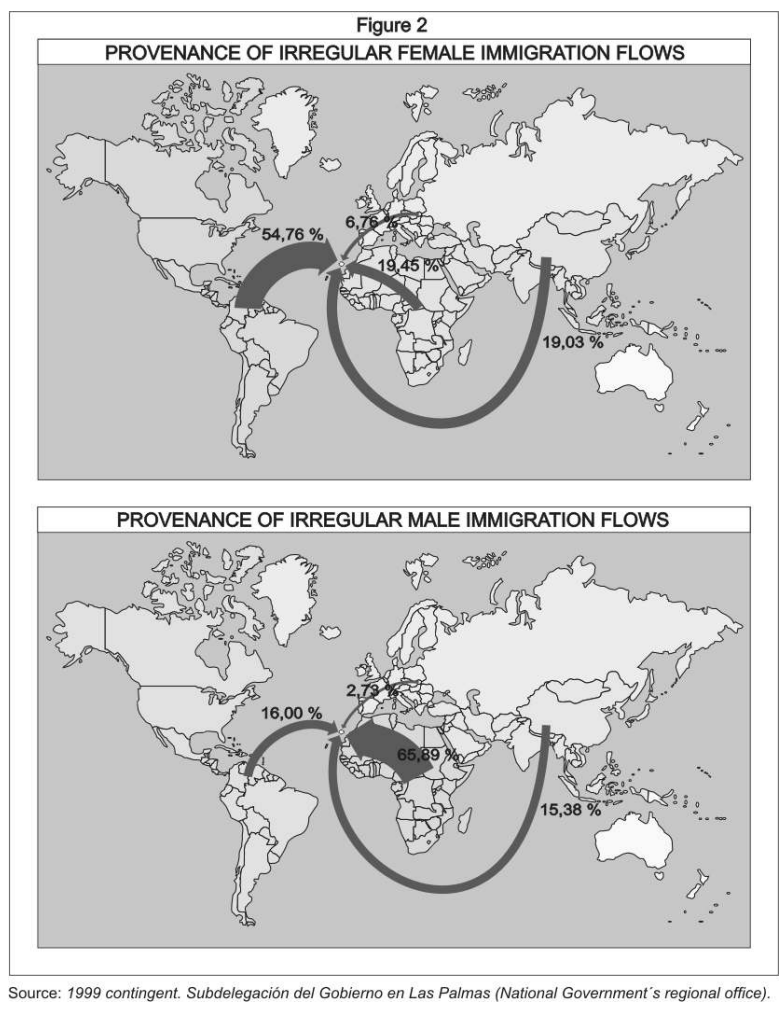

Source: 1999 contingent. Subdelegación del Gobierno en Las Palmas (National Government's regional office)

There is a great variety of origins among irregular immigrants, to the extent that the group arriving from the country where the largest number of immigrating women comes from (Colombia) does not amount to more than $25 \%$ of the total. In the case of immigrating men the situation is different, for here there are certain areas of origin that clearly predominate (Morocco) and there is also a greater number of countries from which immigrants arrive. This difference is clearly reflected, particularly in the cases of South America and Africa, in the gender-based migratory flow maps.

Women arrive in the Canary Islands from all five continents. They bring with them very different cultural references, experiences and motivation. South American women predominate: they come mainly from Colombia, Ecuador, Cuba and the Dominican Republic, followed by women from Argentina and Chile. Over 50\% of immigrating women come from this part of the world. There are two other regional areas of importance in terms of their relevance as sources of migrational flows: Africa and Asia. In the case of Africa, women come mostly from Morocco, Senegal and Equatorial Guinea, whereas in the case of Asia they come mainly from China, The Philippines and India. In both cases they amount to $19 \%$ of the total number of female immigrants who arrive in the Canary Islands.

11 How are we to interpret the peculiarities of these origins as far as immigrating women are concerned? If we regard emigration as an act of freedom, as an exercise of the freedom to move, these flows seem to reflect the fact that women are playing a greater role in certain societies, particularly in South America. Conversely, the lesser importance of female emigration in the case of African countries, specifically Morocco 
and Mauritania, may be regarded as reflecting the situation of social subordination borne by women in these societies.

Some women arrive in the Islands with the purpose of staying for a short period of time, others hope to settle here for good; some have travelled freely, others have been victims of human trade rings. There are among them women who have relatives or friends already residing on the Islands. There are also young women, single and independent, and women with family responsibilities; there are women who are divorced or separated, and there are also those who flee horror and persecution. There are women who seek a better future for their children or for themselves, and women who regularly send money to their families back home. There are women among immigrants who find it difficult to integrate culturally or linguistically, women who come from rural or from urban areas... This diversity of situations calls for a more detailed analysis.

Most Colombian immigrants have been born and have resided in average, large or very large cities (over $65 \%)^{3}$. Only about $7.6 \%$ of these women have been born in rural areas. If we take a closer look at their migratory starting point, it is possible to identify the Department of the Valle del Cauca, as the specific area where most Colombian immigrants come from. It is one of the most densely populated and built-up areas of the country, as shown by the growing percentage of inhabitants registered by the latest censuses in the Department's municipalities: Cali, Palmira, Buenaventura, Cartago, Tulúa, Buga, etc. This is one of the regions that have suffered most as a consequence of the internal conflict affecting the country, and in the year 2000 alone over 2,262 families were forced to leave their homes ${ }^{4}$. It is consequently also the department with the highest percentage of family units were women head the household. The impact of violence and crime, derived from the presence of armed groups, and of drug addiction and alcoholism, has had a domino effect on migrational flows. The resettlement in Cali, Tulúa, Buenaventura, Buga, Sevilla, etc. of those internally displaced from all over the Valle del Cauca, has given rise to the emigration abroad of these cities' native populations.

In a context of political violence and forcible displacement such as the one Colombia is currently going through, it is generally the female population that has to face up to the losses, and when relationships break down it is usually the women who take charge of the family. We think it is significant, in this respect that, which two women reported to CEAR, the Commission for Assistance to Refugees, in the year 2000. The first of them justified her arrival from Colombia saying: I lived in one of the city districts classified as a red zone because of the attacks staged on it by the FARC guerrillas, and I fled to stop them from recruiting my children the way they had recruited other children in the neighbourhood from an early age. The second woman's testimony concerns the situations of ill-treatment still common in Colombia, despite the development of legislation designed to protect women, and it illustrates the break-down in relationships brought about by the situation of political instability. This second woman explained that: I had a stable relationship with a partner who started to mistreat me and eventually left me for another woman. After joining the guerrilla movement she started to threaten me with death, which drove me to leave Colombia and settle in the Canary Islands. 
Table 1. Data derived from the applications for work and residence permits submitted by foreigners at the Delegación del Gobierno (1999).

\begin{tabular}{lrrrr}
\hline GEOGRAPHICAL AREA & Women & Men & \% women & \% men \\
\hline Rest of South America & 242 & 160 & 60.2 & 39.8 \\
Central America & 104 & 136 & 43.3 & 56.7 \\
Maghreb & 102 & 1,417 & 6.7 & 93.3 \\
East Asia & 76 & 138 & 35.5 & 64.5 \\
MERCOSUR countries & 49 & 66 & 42.6 & 57.4 \\
Eastern Europe & 44 & 62 & 41.5 & 58.5 \\
South East Asia & 39 & 38 & 50.6 & 49.4 \\
Gulf of Guinea countries & 38 & 71 & 34.9 & 65.1 \\
South Asia & 22 & 160 & 12.1 & 87.9 \\
Non-EU Western Europe & 5 & 0 & 100.0 & 0.0 \\
North America & 2 & 1 & 66.7 & 33.3 \\
Asia Minor and Egypt & 1 & 13 & 7.1 & 92.9 \\
South Africa & 1 & 3 & 25.0 & 75.0 \\
Central and Eastern Africa & 0 & 4 & 0.0 & 100.0 \\
\hline Total & 725 & 2,269 & &
\end{tabular}

\begin{abstract}
Both reports reflect the convulsive situation Colombia is currently going through. Without this reference it is impossible to explain the importance of the number of Colombian women who are arriving in the Canary Islands. The decision to emigrate, thus, was taken "voluntarily", as a strategy of social, fundamentally family, mobility.

The case of Moroccan women is rather different. Moroccan women generally arrive in the Canary Islands as accompanying family members, and this is why the number of registered applications for work permits is so small compared to the number of consular registrations. Most of them come from an urban environment, about $70 \%$ of the total. It could, in fact, be said that it is in the cities where Moroccan women benefit from greater opportunities to achieve independence or gain access to the labour market, since it is there where the highest rates of women's activities take place and where the most progressive social thinking regarding women is to be found ${ }^{5}$. Nevertheless, Moroccan women are subject to the acute contradiction posed by the ideal - getting married - and the situation of economic crisis, unemployment and lack of alternatives that afflicts cities as well. On very rare occasions do they resort to emigrating in order to overcome this situation (López Lindström, 2000). Consequently, Moroccan women residing in the Canary Islands as immigrants are mostly accompanying family members: daughters, wives or mothers.

To confirm this point, we examined the civil status declared by this group of women ${ }^{6}$ and compared it to that of the group of Colombian women quoted above ${ }^{7}$.

8 The differences between them speak for themselves. Family structure is much more conventional in the case of Moroccan women, and, on their part, Colombian women play a much greater role as family heads since almost $65 \%$ of them have children (several), whether they are married or not, whether in a relationship or divorced.

19 Maternal responsibility is a criterion of decisive weight when these women decide to emigrate. It is not surprising, consequently, that in the interviews held most of them explained that they had arrived in the Islands fleeing from violence, looking for greater freedom and job opportunities, and that they hoped to settle in the Islands for good or at least for several years.
\end{abstract}



have also involved different migratory strategies. They generally arrive as tourists, and some of them benefit from the assistance of relatives and friends, although most of them travel without support of any kind.

Very few Moroccan women look for a job in the Islands, and the proportion of those who arrive on their own is very small, which means that their migratory projects are diametrically opposite to those of Colombian women. According to the data collected from the records of the Spanish Commission for Assistance to Refugees in the Canary Islands for the years 2000 and 2001, the number of women who claimed to have done paid work in their country of origin did not reach $30 \%$ of the total, and that is bearing in mind the fact that these were women who had approached a non-Governmental Organization looking for advice and assistance. In fact, in their case, becoming a wageearning group is linked to a longer stay in the country of reception, as is shown by the fact that most of them had arrived in the Islands three, five or even ten years before contacting the NGO quoted above.

Finally, concerning migratory projects, it is worth pointing out that most immigrating women, not just Colombian and Moroccan women, have relatives or acquaintances who had settled in Spain, more specifically, in the Canary Islands, before their arrival, and that most of them express their wish to bring their families over.

Figure 3. Civil status of Colombian and Moroccan immigrant women.

\section{Figure 3 - Civil status of Colombian and Moroccan immigrant women}

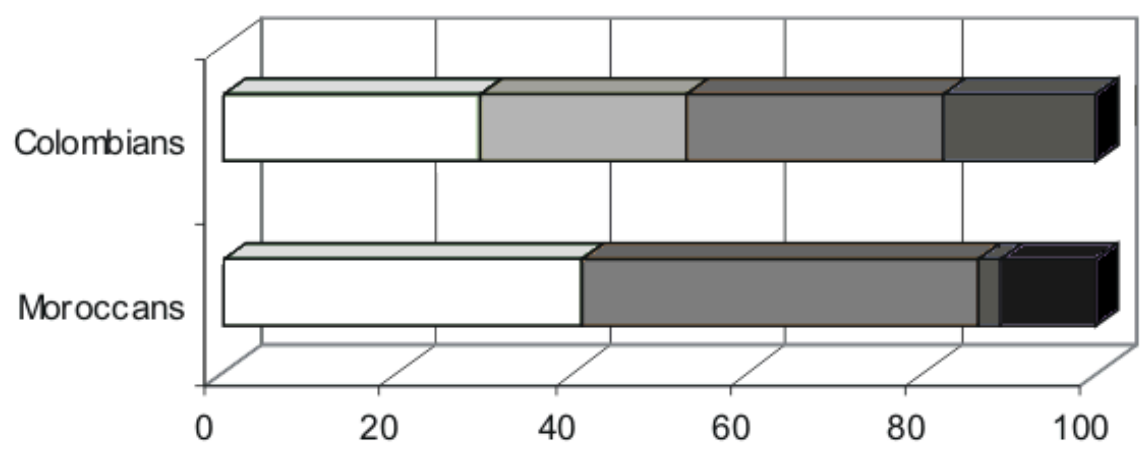

$\square$ Single $\square$ Live with a partner $\square$ Married $\square$ Divorced $\mathbf{Q}$ Widows

In the not too distant future, the processes of family reunification will increase the number of Moroccan women and Colombian men among the immigrants arriving in the Islands. Together with a massive increase in their numbers, immigrating women have also played an increasingly more important role over the last few years, in some cases dragging their husbands and children along in their migratory process, although the kind of work they perform has tended to increase these women's social invisibility (Solé, 1994). In other words, South American women immigrants have played a central migratory role that has driven them to seek their family's reunification, whereas in the case of Moroccan women their numbers will increase in the immediate future on account of the Moroccan men already living on the Islands. These trends seem to lead 
to the perpetuation of the social roles played by women in their countries of origin, although their integration in a different society may bring about certain changes which will have to be analysed in the future.

\section{Immigrating women's levels of training and qualifications}

The heterogeneity of the different groups of immigrants is due not only to factors such as their nationality of origin, their family situation and migratory process, but also to their educational background and qualifications.

Both the beginning and end of migratory adventures are deeply affected by the immigrant's acquaintance with his or her destination's culture and language, and, fundamentally, by the extent of his or her formal training. In the beginning, because the freedom to emigrate is proportional to the level of training and, consequently especially in the case of women -, to the extent of personal independence (Domínguez, Díaz and Parreño, 2001); and in the final stages, because the interaction of the immigrant's own cultural level and the context where he or she has settled will to a great extent condition their process of social and economic integration in the Canary Islands.

We should also add that, especially in the case of the less developed nations, the discriminations women are subjected to in terms of access to formal education and the job market, among others, generate a further, more subtle motivation to emigrate: the search for a society of greater economic and social fairness (Ramírez, 1998).

In order to examine this issue more closely, we have studied the data provided by CEAR Canarias for the years 2000 and 2001. This is the least biased source, and the one closest to actual migratory flows 8 .

As we may observe in Figure 4, the average immigrant arriving in the Islands has been through secondary or higher education, and it is worth pointing out that in many cases women benefit from a higher level of education than men. Especially, since these women often tend to take up jobs for which they are overqualified, which may partly be due to the demands of the labour market and these women's limited work experience, but also because there is no formal recognition of their skills (Solé, 1994).

Figure 4. Immigrant's level of education according to data provided by CEAR.

Figure 4 - Immigrant's level of education according to data provided by CEAR
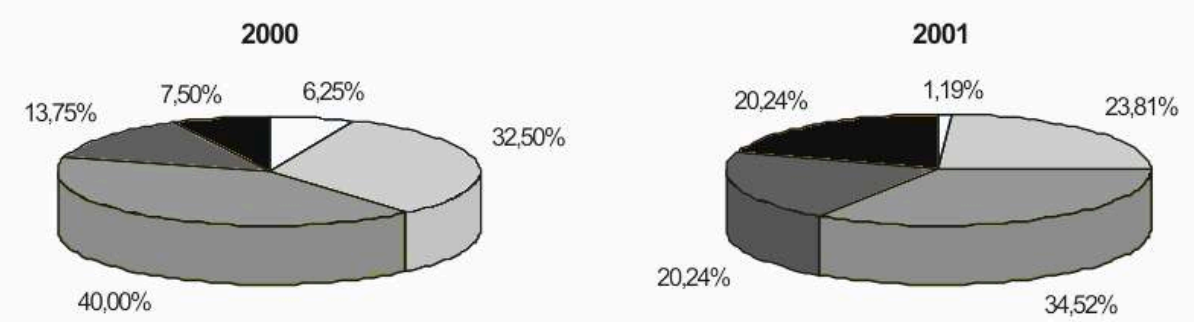

$\square$ No studies $\square$ Primary studies $\square$ Secondary studies $\square$ Occupational training

Higher Education 


\section{country of origin.}

Figure 5. Levels of education according to region of provenance. Data provided by CEAR (2000-2001).

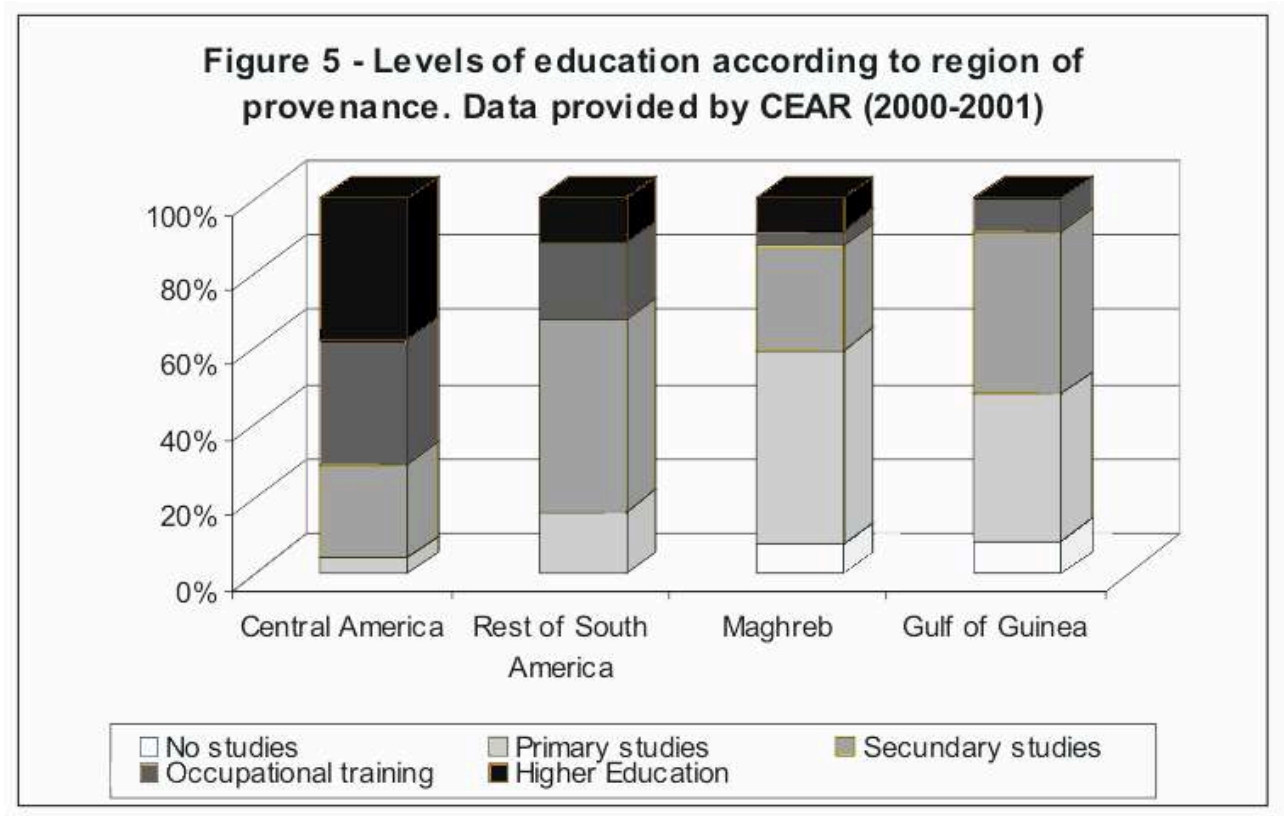

The highest levels of formal education are to be seen in the column representing immigrants coming from Central America, mostly Cubans, where over a third have a university degree and a similar percentage has some kind of specialized occupational qualification. The rest, about 25 per cent, have at least completed their secondary schooling, and only about $4.16 \%$ have merely completed primary studies.

The column that represents the Rest of South America, mostly Colombians and, to a much lesser extent, Ecuadoreans and Venezuelans, shows a similar academic profile. In this case, the socio-political conflicts Colombia is going through has had the effect of increasing the numbers of those women with primary and secondary studies especially the latter - at the expense of the number of those with higher qualifications. 
In any case, it is worth underlining the importance of the high levels of formal training displayed by the women arriving from Colombia, given the fact that the extended rates ${ }^{9}$ of female child labour are ostensibly higher in all age groups than male child labour rates, a fact which undoubtedly has a negative effect on the girls' opportunities to receive some form of formal education and on school absenteeism, and, ultimately, on the levels of training and qualifications of Colombian women.

African women, on the other hand, display very low levels of training and qualifications. For example, over half of Moroccan women, who belong to one of the largest contingents of immigrants in the Canary Islands, only have primary or the most elementary studies. Nevertheless, there are also some who have had access to higher education, although in this case, and given their country's geographical proximity to the Canary Islands, their motivation is usually to complete their studies, which might in turn become a first step towards a more definite establishment in the Islands.

One of the most dramatic aspects of the migratory phenomenon has to do with the small but important group of women, about $8 \%$ of the total, who come from the heart of Africa with no form of training or schooling at all. This group requires a special effort on the part of public administration and NGOs in order to acquaint them with their rights and to facilitate their process of integration, which is more complex than in the case of other immigrant women.

The rest of the immigrants arriving from the Gulf of Guinea display the same features in terms of training and qualifications as their Moroccan counterparts, except for the fact that in their case there are no women with university studies, thereby increasing the number of women who give up their studies once they finish their secondary education.

The knowledge of languages may either complicate or facilitate the process of integration. In the last few years, about $22 \%$ of the women who arrived in the Canary Islands did not speak Spanish. This is the case of most Asian and Eastern European women, and of about $50 \%$ of Moroccan and Subsaharian women. Paradoxically, it is these very same groups that claim to speak several languages ( 3 or more), a fact which may be attributed to the processes of national disintegration in the case of Eastern Europe and the former USSR, and to the processes of colonization in the African continent.

Summarizing, South American women, on the strength of their formal training and their cultural proximity to local society, seem to be in a better position to settle successfully in the Canary Islands. On the other hand, their lack of cultural and linguistic references makes it much more difficult for women from the Maghreb and the Subsaharian region to complete their process of integration (Setién, 2000).

\section{The labour market: the substitutive role of working immigrant women}

39 In the previous sections, we have analysed women's immigration from the point of view of the areas of origin. In this section, we shall deal with the Canary Islands and their productive structure as a point of reception for migrational flows. In other words, the integration of immigrant women in the labour market is due, fundamentally, to the 
economic evolution and the social structure of the geographical region they have arrived in.

Over the last few years, and coinciding with the period of economic expansion that went from 1996 to 2001, there have been important changes in the traditional characteristics of Canarian society. These changes are the direct consequence of the effects the specialization in tourism have had, and of the new post-industrial forms Canarian society has adopted.

During this period, both the rates of employment and salaries have grown at a higher pace than the rate of average inflation. Aggregate demand has been reactivated and consumer spending has recovered given the higher rate of employment, the high numbers of foreign tourists and the fall in both interest rates and inflation. All economic sectors have, to a greater or lesser extent, taken part in the Islands' economic growth. Nevertheless, the Islands' economic recovery has been based, above all, on the service sector, where jobs have been created at a higher rate than in the other productive sectors, especially in the building industry and business services; public administration, defence and social security; domestic service; the hotel trade and education. In 1999, $71.9 \%$ of the working population was employed in the service sector, and it represented 78.2\% of the Gross Added Value of Canarian economy (Domínguez, Díaz and Parreño, 2001).

42 It is in this tertiary sector where the integration of immigrant women takes place, mainly in the area of domestic service (they represented $57.4 \%$ of the applications for work permits submitted in 1999), and, secondly, in the hotel trade (21.2\%).

The case of domestic service reflects the structural tendency generally displayed by developed economies to generate a continuous demand for workers willing to perform lowly badly-paid tasks (González Ferre, 2000). As Canarian women have gradually entered the labour market and, consequently, the formal economy, there has been a parallel increase in the demand for domestic service. Reproductive activities and, particularly, childcare and looking after the elderly have become tasks that can no longer be performed by native working women. The rise in the standard of living of the local population as well as the new labour market niches to which local women have gained access, have meant that the lowly badly-paid jobs formerly carried out by unskilled local women have now become vacant. This is why many families currently resort to hiring foreigners to perform these tasks.

44 Among the women from the Maghreb, the Subsahara, South East Asia and Central America, who applied for a work permit in 1999, about three out of every five had a job of this kind. $72.22 \%$ of the Colombian immigrant women the Spanish Commission for Assistance to Refugees (CEAR) dealt with in 2000 and 2001 were also engaged in this area of work. In the case of Senegal and Ghana, $84.21 \%$ of immigrant women were employed in the sector of domestic service, according to the CEAR.

The hotel industry is also one of the most important sources of jobs for immigrant women. The recent evolution of the tourist industry in the Canary Islands has brought about the construction and opening of hotels, apartments, restaurants and so on, which has in turn given rise to an important demand of labour force. Consequently, many immigrant women have taken up jobs as "chambermaids", "kitchen staff", "waitresses" or "cooks", which are obviously similar to the jobs carried out in the sector of domestic service. With the exception of immigrant women coming from East Asia, who generally 
tend to find work at restaurants and hotels, about one out of every five immigrant women find work in this sector. The data collected reveals that these women frequently change jobs within these sectors, and many claim to have worked in both (domestic service, childcare, care for the elderly, as waitresses, cooks and so on). Nevertheless, the hotel industry generally represents a higher rung in the working career of immigrant women. There are a number of reasons for this: the greater freedom from personal dependence it entails, the greater amount of free time it affords given the fact that working days are regulated by law, the lesser degree of invisibility of this kind of work, and so on. The information collected from CEAR files corroborates this.

Immigrant women with specialist technical qualifications or university studies offer a different picture. Their working activities are more varied, their qualifications enabling them to choose from a wider range of professional choices. This is especially so in the case of women from Cuba, the southern end of South America and Eastern Europe. The latter tend to work in the service sector, in jobs to do with commerce, clerical work, teaching, as artists... in short, a wide range of jobs, although the hotel industry and domestic service still represent the main sources of work.

On the other hand, the most unskilled immigrants coming from Africa or from Central or South America were the only ones who applied for a work permit as agricultural labourers, a sector where a gradual substitution of the local workforce is also taking place. The hard work involved in harvesting tomatoes, peppers, aubergines and other extra-early greenhouse-grown produce that the Canary Islands export to European countries have only been sought by those immigrants who had little chance of doing any other work, or by those who had not even found a job in their countries of origin: women from Ghana, Senegal, Mauritania, Morocco and Ecuador.

The seasonal nature of these jobs, however, generates a certain degree of instability, and in fact many of them claim to have worked as domestic servants as well.

These circumstances also explain why many immigrants end up taking on irregular jobs. The lack of proper work contracts, verbal agreements that involve no formal acknowledgement at all of the work done, and so on, are rather common in the immigrant labour market. The same can be said for other kinds of black-market jobs that can be described as criminal or illegal, such as drug trafficking and prostitution.

According to a report drawn up by the NGO Médicos del Mundo (Spanish branch of Doctors of the World), the increase in the number of immigrants in the Canary Islands has trebled prostitution in the last two years, mostly in highly-populated areas (Hernández, 2002), a fact that has led to the opening of a healthcare centre for prostitutes in Las Palmas de Gran Canaria.

51 Out of the first 66 women the said centre dealt with in the first two and a half months after its opening, 65 were immigrants. Those in charge of the NGO explain that this increase is due to the worsening of the situation in the prostitutes' countries of origin, the relative social tolerance prostitution itself benefits from and the ease with which criminal gangs operate in our country. In any case, we should refrain from recriminating the victims of this activity, even if they are generally aware of the fact that they have to resort to this kind of "work" to be able to pay for their travelling and earn an income that will enable them to reside in the Islands. 
Figure 6. Rates of employment in the hotel trade and in the domestic service according to training and qualifications data provided by CEAR (2000).

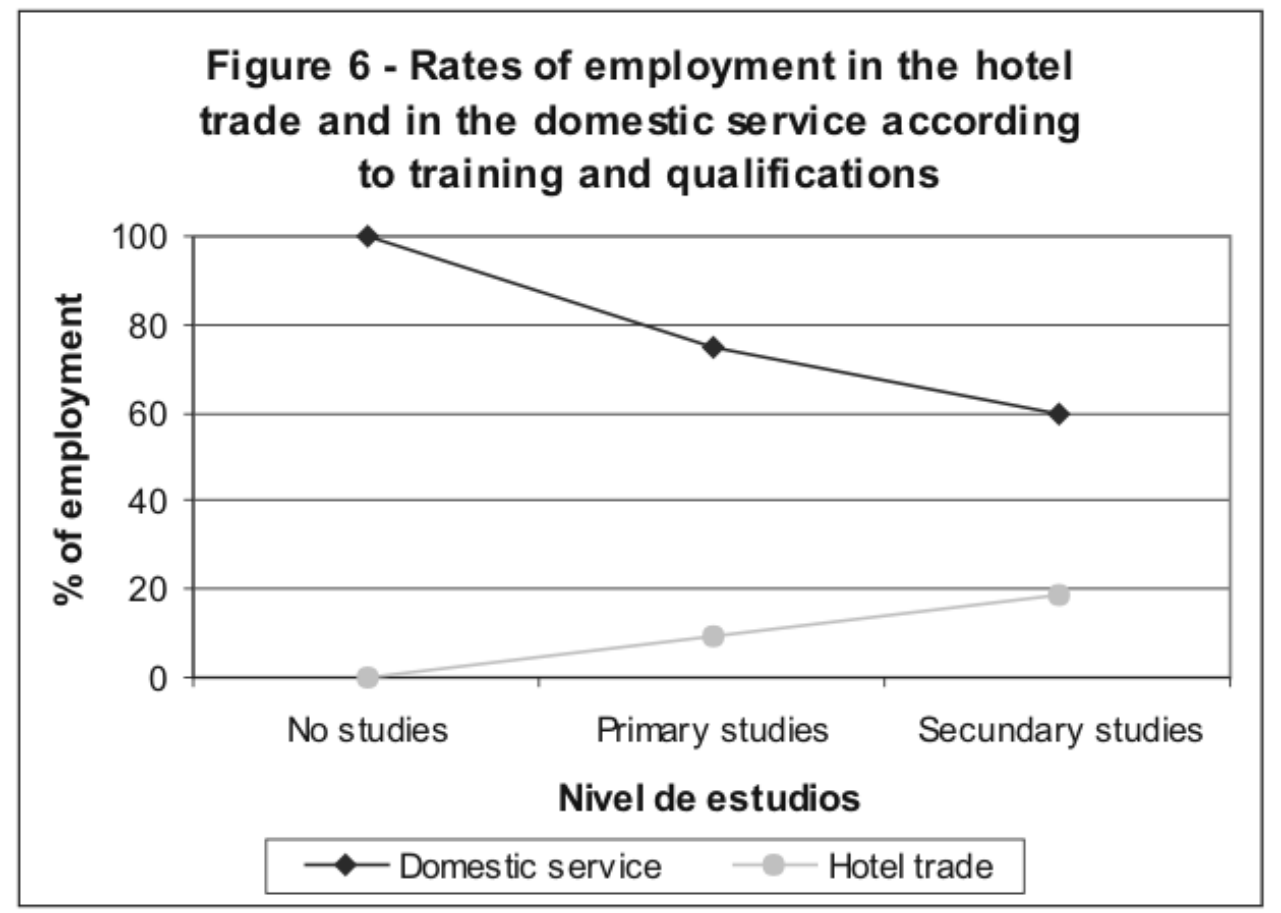

\section{Conclusions}

We have established that, at the turn of the $21^{\text {st }}$ century, in Spain, and particularly in the Canary Islands, a territory that serves as the European Union's southernmost border, women are increasingly playing a greater role in migratory flows.

In the last few years, irregular migratory flows have become much more intense on the strength of the Islands' cultural affinity in the case of South American women, geographical proximity to Africa and the development of the Islands' informal economy.

A considerable number of women arrive in the Islands from all over the world, who bring with them a wide variety of cultural references and motivations. The largest national group of immigrants (from Colombia) does not reach $25 \%$ of the total, and it is followed, at a certain distance, by the Moroccans.

The Colombian women come mainly from the cities of the Valle del Cauca, driven by this area's situation of political violence and forcible displacement. Moroccan women, however, arrive in the Islands as accompanying family members. They are mostly daughters, wives or mothers of immigrant men, and consequently very few of them enter the Islands' labour market.

Concerning these women's migratory project, it is worth pointing out that most of them have relatives or acquaintances who had already settled in the Islands before them, and that they express their wish to bring other members of their family over in the near future.

Most of them have some sort of secondary or even university education, a level of formal education which is higher than that of their male counterparts. Central 
American women and, especially Cuban women, display the highest levels of formal training.

Conversely, the lowest levels of formal training and qualifications are to be found among the women who come from Africa.

Immigrant women tend to enter the local labour market through the tertiary sector, mainly domestic service (57.4\% of the applications for work permits submitted in 1999) and, secondly, the hotel trade (21.2\%).

The jobs linked to the tourist industry in the Canary Islands generally occupy a higher rung in the working career of immigrant women, the more highly qualified women taking on the widest variety of jobs (commerce, administration, teaching...). Nevertheless, there is a great irregularity to be found in their career development.

\section{BIBLIOGRAPHY}

BELTRÁN ANTOLÍN J. (2000), “Expansión geográfica y diversificación económica. Pautas y estrategias del asentamiento chino en España”, II Congreso de la Inmigración en España, Universidad de Comillas, Madrid.

BONILLA-CASTRO E. Comp. (2000), Formación de investigadores - II. Dinámicas de la realidad social colombiana, Tercer Mundo Editores, S.A. Santafé de Bogotá.

DOMÍNGUEZ MUJICA J. (1996), La inmigración extranjera en la provincia de Las Palmas, Ed. CIES, Las Palmas de Gran Canaria.

DOMÍNGUEZ J., DÍAZ R. y PARREÑO J.M. (2001), Inmigración extranjera e integración. La inmigración irregular en Canarias, Consejería de Empleo y Asuntos Sociales, Gobierno de Canarias, Las Palmas de Gran Canaria.

GONZÁLEZ FERRER A (2000), "Impacto de la mano de obra inmigrante sobre el mercado de trabajo nacional” II Congreso sobre la inmigración en España, Universidad de Comillas, Madrid.

HERNÁNDEZ M.J. (2002), "La inmigración triplica en dos años el ejercicio de la prostitución en las Islas" La Provincia-Diario de Las Palmas, 25 de enero.

LÓPEZ LINDSTRÖM A (2000), "La prostitución de mujeres marroquíes en España: mito y realidad", II Congreso sobre la inmigración en España, Universidad de Comillas, Madrid.

MARTIN RUIZ J.F. (1987), Canarias: entre el éxodo y la inmigración, Ed. Cabildo Insular de Tenerife y CCPC, Santa Cruz de Tenerife.

OSO CAÑAS L. (2000), "Estrategias migratorias de las mujeres ecuatorianas y colombianas en situación irregular: servicio doméstico y prostitución en Galicia y Pamplona”, II Congreso sobre la Inmigración en España, Universidad de Comillas, Madrid.

RAMÍREZ BACCA R. (1998), “Exilio y género. El caso de la mujer colombiana en Suecia”, Invandraren, 3/4. Göteborg, pp. 28-29.

SETIÉN M.L. (2000), "Perfiles y tipologías de las mujeres inmigrantes en Bilbao”, II Congreso sobre la inmigración en España, Universidad de Comillas, Madrid. 
SOLÉ C. (1994), La mujer inmigrante, Ministerio de Asuntos Sociales, Instituto de la Mujer, Madrid.

\section{NOTES}

1. Ley Orgánica 4/2000, of 11 January, sobre Derechos y Libertades de los Extranjeros en España Orgánica (Public General Act governing the rights and freedoms of foreigners in Spain) and their Social Integration.

2. Order in Council 864/2001, of 20 July, whereby the implementing regulation of the Ley Orgánica 4/2000 (Public General Act), reformed by the Ley Orgánica 8/2000 (Public General Act), of 22 December, is passed.

3. We have collected this data from the contingent of work and residence permits filed in 1999.

4. Information quoted from Diagnóstico de Población Desplazada y Comunidades de Recepción en Seis Departamentos de Colombia (Diagnosis on Displaced Population and Reception Communities in Six Departments in Colombia), published on the International Migration Organization's web site (http://www.col.ops-oms.org/desplazados).

5. In this respect, the study undertaken by Mrs. Souad-el Hadri on the situation of women in Morocco is very informative. It is to be found on the following web site: www.pangea.org/ ariadna/demograf-souad.htm

6. Only registered women over 14 years of age were taken into account.

7. To establish the marital status of Colombian women we have made use of the information contained in the interviews held with them at the Delegación del Gobierno de Canarias during the process of regularization held in 2000.

8. Both the information provided by the Red Cross and the data collected from the interviews distort the immigrants' real academic profile: in the case of the Red Cross, because since it is an organization that deals with the least favoured groups its data is downwardly biased; whereas the information derived from the interviews concerns women who dealt with their own paperwork, more independent and with a higher academic level than average, as evidenced by the fact that the only two Moroccan women who were interviewed were both university students.

9. This rate differs from traditional child labour rates in that it includes housework, whether at home or elsewhere, when analysing rates of labour among children and young people.

\section{ABSTRACTS}

During the last fifty years, the Canary Islands have experienced a radical change in terms of foreign mobility flows. On the strength of the tourist boom that took place during the 1960 s and 70 s, the Islands changed their traditional emigratory role into an immigratory one. Over the last few years, these migration flows have reached their peak with over 61,000 new foreign residents registered. This development has led to this Ultraperipheral Region having the second highest rate of resident foreigners in Spain. This latest migratory stage has been characterized by the large number of irregular immigrants who have arrived from underdeveloped countries such as Morocco, Colombia and Mauritania. Doubtlessly linked to this process, there has been a notable increase in the female population living in the Canary Islands. These female immigrants are replacing native women in unskilled and badly paid jobs. Given this situation, a gender study may 
contribute to the development of a plural, multi-ethnic and intercultural way of living that will neutralize the dangers of discrimination and racism in the Canary Islands.

$\mathrm{Au}$ cours des cinquante dernières années, les îles Canaries ont subi un changement radical en termes de flux de mobilité des étrangers. En vertu du boom touristique des années 60 et 70, le rôle émigratoire de l'archipel est devenu immigratoire. Ces flux de migration ont atteint leur maximum ces dernières années, avec plus de 61000 nouveaux résidents étrangers recensés. Une telle conjoncture a conféré à cette région ultrapériphérique le deuxième taux le plus haut d'étrangers résidant en Espagne. La dernière étape migratoire a été caractérisée par le grand nombre d'immigrants irréguliers qui sont arrivés des pays sous-développés comme le Maroc, la Colombie et la Mauritanie. Ce processus explique l'augmentation notable de la population féminine vivant aux Canaries: ces immigrantes remplacent des femmes natives de l'endroit dans des emplois non qualifiés et mal payés. $\mathrm{Vu}$ la situation, nous pensons qu'une étude de genre pourrait contribuer au développement d'un mode de vie pluriel, multi-ethnique et interculturel qui neutraliserait les dangers de discrimination et de racisme dans les Îles Canaries.

\section{INDEX}

Keywords: migration flows, inmigratory role, gender, unskilled jobs, multi-ethnic way of living, Canary Islands

Mots-clés: flux de migration, rôle immigratoire, genre, emplois non qualifiés, mode de vie multi-ethnique, les Canaries

\section{AUTHORS}

\section{JOSEFINA DOMÍNGUEZ MUJICA}

Grupo de Investigación “Geografía Económica y Social”, Universidad de Las Palmas de Gran Canaria,jdominguez@dgeo.ulpgc.es

\section{RAQUEL GUERRA TALAVERA}

Grupo de Investigación “Geografía Económica y Social”, Universidad de Las Palmas de Gran Canaria, rguerra@becarios.ulpgc.es 